\title{
混練装置を利用した加硫ゴムの高温微粉砕
}

\author{
吉海 $\quad$ 和正 $* 1 \cdot$ 藤 道治 $* 2 \cdot$ 姫野成以子*3

\section{Fine Grinding of Vulcanized Rubber Using Kneading Equipment at High Temperature}

Kazumasa YOSHIKAI ${ }^{1}$ (Chemical and Textile Industry Research Institute, Fukuoka Industrial Technology Center 3-21 Kamikoga, Chikushino, Fukuoka 818-8540, Japan), Michiharu TOH ${ }^{2}$ (Department of Biochemistry and Applied Chemistry, Kurume National College of Technology, 1-1-1 Komorino, Kurume, Fukuoka 830-8355, Japan) and Seiko HIMENO $^{3}$ (R \& D Department, Kurume Research Park Co.,Ltd., 2432-3 Aikawa-machi, Kurume, Fukuoka 839-0861, Japan))

Vulcanized rubbers were comminuted to particle diameter with 1-5mm by cutting mill. Then, the particles were mixed with filler such as silica at roughly $100-150{ }^{\circ} \mathrm{C}$ in mixer and twin screw extruder. Fine powders of rubber wastes having the mean particle diameter of about $297-500 \mu \mathrm{m}$ were obtained. It can be expected that this method is utilized to the recycling of a rubber waste.

(Received on June 21, 2004)

(Accepted on October 29, 2004)

Key Words : Vulcanized rubber, Twin screw extruder, Fine grinding, Filler, Recycling

\section{1. 緒言}

加硫ゴム製品の成型加工工程において発生するバリなど の工場内廃裹物は，ほとんどが再利用されることなく処分 されている．これは，加硫ゴムの廃率物が小量多品種であ ること, 加硫ゴムが三次元架橋構造を有する難リサイクル 材料であることなどによると考えられる. しかし, 最終処 分場の枯渴等により廃棄物の処分費用は今後上昇すること が予想され, 再利用されていないゴム廃棄物をいかに再利 用して行くかは大きな課題となると考えられる. 三次元架 橋構造を有する高分子材料のリサイクルを考える場合, 単 純ではあるがしばしば有効な方法となるのは微粉砕して増 量剂として再利用する方法である.工場内廃累物であれば, 基本的には配合や加硫成型条件などが明らかであり, 発生 源毎に分別することも可能である. 分別され素性が明らか な加硫ゴム廃裹物を, 微粒子状のゴム粉として再生すれば, 製品の原料ゴムに一定量配合して再利用することは十分可 能であろうと考えられ，加硫ゴムの工場内廃棄物のリサイ クル状況の改善につながると考えられる. 課題は, 小量多 品種の加硫ゴム廃棄物を小ロットで効率よく微粉砕する技

\footnotetext{
*1福岡県工業技術センター化学瀻維研究所 $(\overline{\mathrm{T}} 818-8540$ 筑紫野市上 古賀 3丁目 2-1)

*2 久留米工業高等専門学校生物応用化学科 ( T 830-8355 久留米市小 森野 1-1-1)

*3(株久留米リサーチ・パーク（～839-0861 久留米市合川町 2432-3）
}

\section{術の開発である。}

加硫ゴムは高いゴム弾性のため微粉砕することは容易で はなく, しばしば液体窒素等で冷却してゴム弾性を消失さ せた上で微粉砕が行われている ${ }^{1,2)}$. 一方, 加硫ゴムは $100{ }^{\circ} \mathrm{C}$ 以上の高温下では強勒性が急激に低下し， $150{ }^{\circ} \mathrm{C} て ゙$ は強靭性の尺度である抗張積が室温での 10 分の 1 以下に まで低下する場合もある ${ }^{3)}$. このことは, 高温下では加硫 ゴムを比較的容易に破壊して微粉砕することが可能である ことを示している. 筆者らは, 加硫ゴムの微粉砕方法とし て 2 軸押出機のような混練装置を利用して, 高温下で高せ ん断力を負荷して微粉砕することを検討した.

混練装置によって負荷される高せん断力を架橋高分子材 料等の難リサイクル材料のリサイクルに利用することは, 近年盛んに検討されている方法である ${ }^{4-9)}$.ゴム関連でも， 2 軸押出機を用いて高温・高せん断力下で脱硫して再生ゴ ム化する技術が開発されている10,11). また, 石臼型押出 機 ${ }^{12 ）}$ や密閉式混練装置 ${ }^{13,14)}$ を利用して加硫ゴムを微粉砕 する技術も検討されている. 混練装置は $150{ }^{\circ} \mathrm{C}$ 程度の温度 は容易に設定可能であり, 高温下で強䩲性の低下した加硫 ゴムは負荷される高せん断力で容易に破壊可能と考えられ る. また, 混練装置は比較的小ロットでの処理が可能であ り, 温度やせん断力の設定範囲を広範囲に変えることも容 易に可能である.したがって, 混練装置を利用した加硫ゴ ムの微粉砕方法は, 加硫ゴムを小ロットで微粉砕可能な方 
Table 1 Formulation of the SBR sample

\begin{tabular}{cc}
\hline Material & Content \% \\
\hline SBR & 100 \\
ZnO & 3 \\
StAc *1 & 3 \\
S & 1.75 \\
C. B. (HAF) & 50 \\
BBS *2 & 1 \\
oil & 9 \\
\hline * Stearic Acid & \\
*-tert-butyl-2-benzothiazole sulfenamide \\
Table 2 Composition of the NBR sample \\
Component & Content \% \\
\hline extraction fraction & 15.6 \\
rubber & 42.2 \\
C. B. & 36.6 \\
ash & 5.6
\end{tabular}

法であり, 加硫ゴム廃裹物のリサイクルへ利用されること が期待できる.

\section{2. 実験}

\section{1 加硫ゴム試料}

粉砕する加硫ゴム試料は, JSR (株) 製のカーボンマス夕 ーバッチ $\mathrm{CH}-50$ を用いて $2 \mathrm{~mm}$ 厚にプレス加硫して作製 したスチレンブタジェンゴム (SBR)のシート (SBR 試料), Nipol 1042 (日本ゼオン (株) 製, 中高ニトリル)をベースと

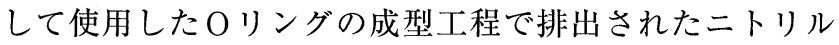
ブタジェンゴム (NBR)のバリ（NBR 試料）を用いた. SBR 試料は $\phi 150 \mathrm{~mm}$ テストロールを, NBR 試料は(株) ホーラ イ製粉砕器 UG-210を，各々用いて $1-5 \mathrm{~mm}$ 程度に粗粉砕 して高温微粉砕の実験に供した. Table 1 にSBR 試料の配 合を示す。また，Table 2 にNBR 試料の主な配合の分析 結果を示す. SBR 試料の作製に使用したゴムの各種架橋 剂(酸化覀鉛・ステアリン酸・硫黄・BBS) は市販品を用 いた.ゴム粉の凝集防止剂として用いたフィラーは，湿式 シリカ (ニプシールVN3 : 日本シリカ製), 乾式シリカ (ア エロジル＃200：日本アエロジル製)，カーボンブラック (HAF旭＃70：旭カーボン製)，酸化覀鉛 $(3$ 号亜鉛華 : 白水化学製), 炭酸カルシウム (重質炭酸カルシウム: 熊本 鉱業製)，タルク(福岡タルク製)を用いた。

\section{2 バッチ式混練装置による高温微粉砕}

粗粉砕したSBR 試料を，ブラベンダー社製プラスチコ ーダーPL-2001に装着したバッチ式の試験用混練装置(容 量 $55 \mathrm{ml}$, ローラー型ブレード) を用いて高温微粉砕を行っ た. 設定温度は $80 \sim 150{ }^{\circ} \mathrm{C}$, 混練装置のブレード回転数は 80rpm, チャンバー内へのゴムの充てん率は $80 \%$ とした. 作製したゴム粉は，ふるい分級して粒径分布を求めた。 Fig. 1 に実験に用いた試験用混練装置のチャンバー部分の

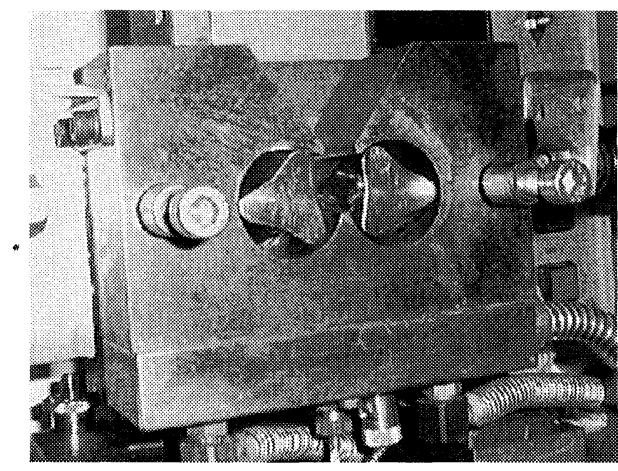

Fig. 1 Chamber part of the test mixer used for the preliminary experiment.

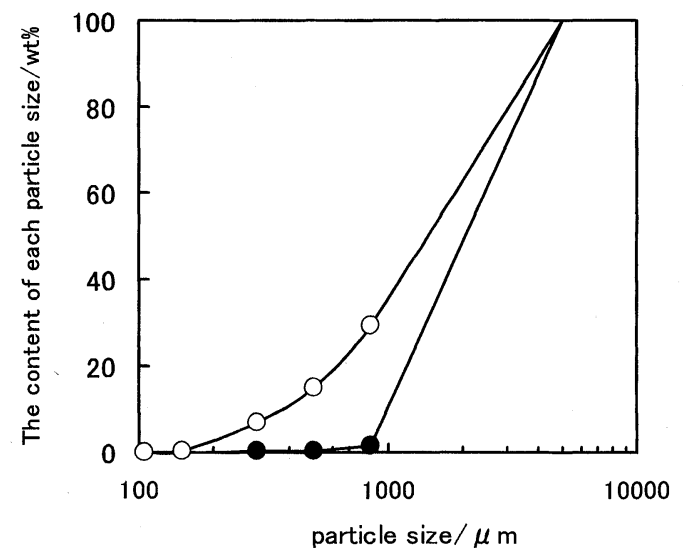

Fig. 2 Particle size distributions of the SBR sample before and after high-temperature fine grinding. ( shows the data before fine grinding and $\bigcirc$ shows the data after fine grinding.)

写真を示す.

\subsection{2 軸押出機による高温微粉砕}

粗粉砕した加硫ゴム試料を神戸製鋼所製の 2 軸押出機 KTX-37(スクリュー径：37mm，L/D：30，スクリュー/ バレルギャップ：0.3mm, 同方向回転)を用いて連続プロ セスで高温微粉砕することを検討した.

\section{3. 結 果 と 考 察}

\section{1 バッチ式混練装置による高温微粉砕}

設定温度： $100{ }^{\circ} \mathrm{C}$ で SBR 試料の高温微粉砕を行った. 試 料投入完了から装置停止までの粉砕時間は 5 分とした. Fig. 2 に高温微粉砕の前後における試料の粒径分布を示 す. 高温微粉砕によって $500 \mu \mathrm{m}$ 以下の微粒子成分が生成 してはいるが, 多くは $840 \mu \mathrm{m}$ 以上の粗大な粒子であった。 高温微粉砕後の粗大な粒子は，微粒子同士が融着したよう な形態を示していた。また，この融着は強固ではなく，ほ ぐすことが可能であった，高温によってゴム粉の表面が可 塑化して融着が生じたものと考えられる，粗大な粒子が微 粒子の融着で形成されていることは, 高温と高せん断力に よって加硫ゴムの破壊による微粒子化自体は進んでいるこ とを示す.したがって, 融着を効果的に防ぐことさえでき 


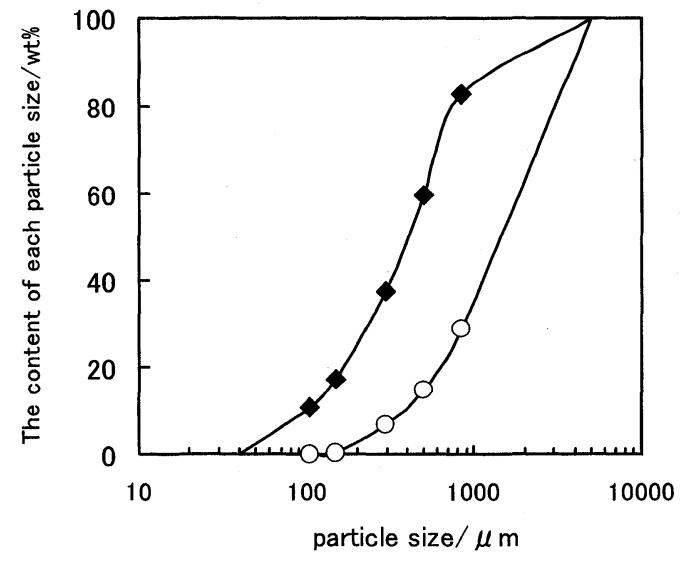

Fig. 3 Particle size distributions of the SBR samples after hightemperature fine grindings in the cases where silica was added and not added. ( shows the case in which silica was added and $\bigcirc$ shows case in which the silica was not added.)

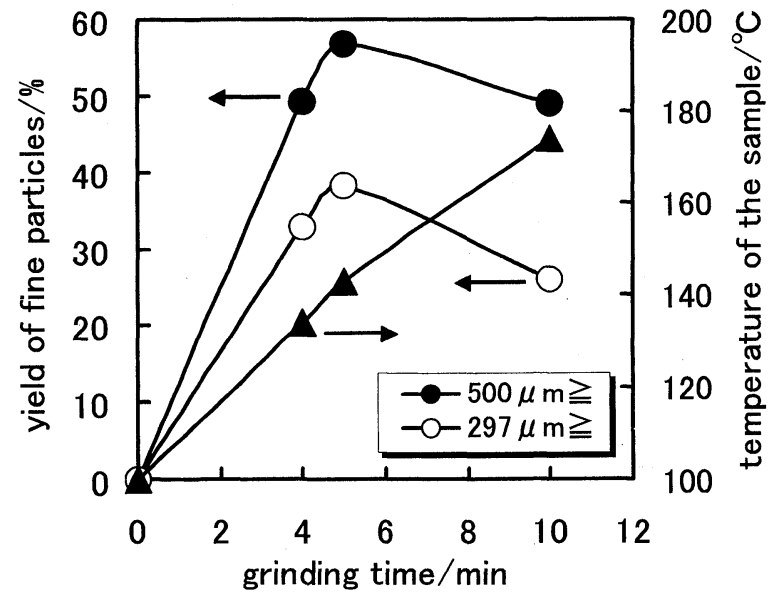

Fig. 4 Grinding time dependences of the fine particle yield and the sample temperature.

れば微粒子成分を高収率で回収可能であると考えられる. そこで，シリカ等のフィラーを粉研時に添加して打ち粉の ような働きをさせることによって融着を防止することを検 討した.

\section{2 フィラーの添加による融着防止}

SBR 試料に対してフィラーを添加した上で，試験用混 練装置に投入して高温微粉砕を行った。フィラーは, 湿式 シリカ(以下単にシリカと記述), カーボンブラック, 乾式 シリカ，酸化亜鉛，タルク，炭酸カルシウムを用いた．添 加量は, シリカを用いた場合は試料に対して10重量部を 基本とし，他のフィラーの場合はシリカの 10 重量部と同 一体積となる量を添加した。

Fig. 3 に, シリカを添加した上で高温微粉砕を行って得 たゴム粉の粒径分布を, フィラーを添加せずに高温微粉砕 を行って得たゴム粉の粒径分布とともに示す. シリカを添 加したこと以外の条件は，3.1の場合と同様である.シリ カを添加することで $500 \mu \mathrm{m}$ 以下の微粒子成分の収率が約

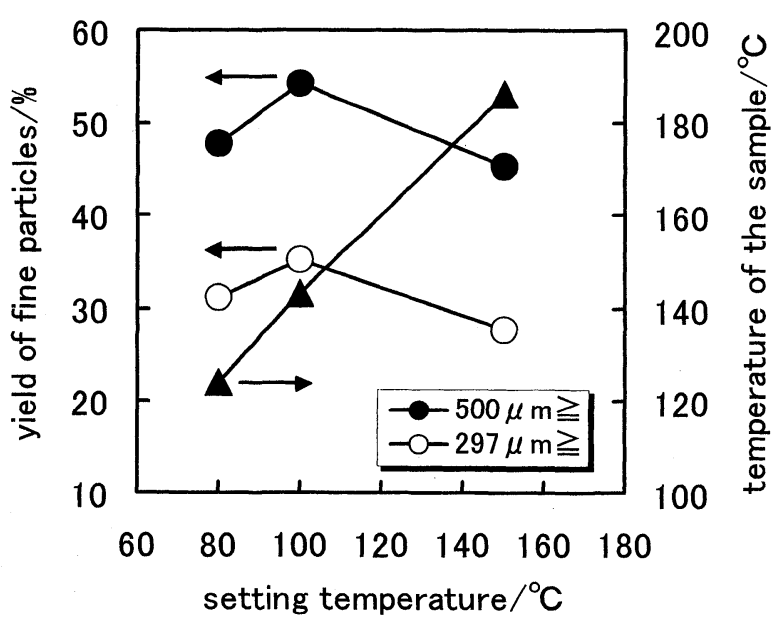

Fig. 5 Setting temperature dependences of the fine particle yield and the sample temperature.

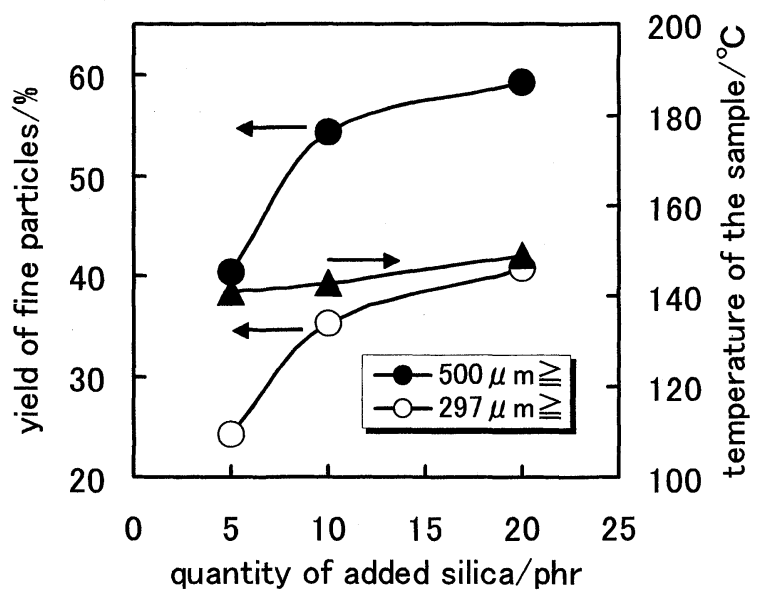

Fig. 6 Quantity of added silica dependences of the fine particle yield and the sample temperature.

60wt\%にまで向上しており, シリカの添加が微粒子成分 の収率向上に有効であることが確認できた。

Fig. 4 に, シリカを添加して高温微粉砕を行った場合の, 粉砝時間と $297 \mu \mathrm{m}$ 以下及び $500 \mu \mathrm{m}$ 以下の微粒子成分の 収率および試料温度との関係を示す。シリカを添加したこ とと粉砕時間以外の条件は，3.1の場合と同様である．粉 砕時間が 5 分を超えると収率が低下しているが，これは試 料温度の上昇と高温下での長時間の混練により表面の可塑 化が進んだためではないかと考えられる．Fig. 5 に設定温 度と微粒子成分の収率および試料温度との関係を示す．粉 砕時間は 5 分で, 温度以外の条件はFig. 4 の場合と同様で ある。試料温度は, 発熱のため設定温度より $40^{\circ} \mathrm{C}$ 程度上 昇した，微粒子成分の収率は設定温度に対して極大值を示 し，設定が高温になり過ぎると収率は低下した。温度上昇 とともに強勒性は低下し粉砕は容易になるが，過度の高温 下では表面の可塑化が進みシリカによる融着防止効果が発 揮し難くなるためと考えられる. Fig. 6 にシリカの添加部 数と微粒子成分の収率および試料温度との関係を示す．粉 砕時間は 5 分で, シリカの添加部数以外の条件はFig. 4 の 
Table 3 The condition and result of the high-temperature fine grinding in changing a filler

\begin{tabular}{lcccccc}
\hline & No. 1 & No. 2 & No. 3 & No. 4 & No. 5 & No. 6 \\
\hline rubber & 100 & 100 & 100 & 100 & 100 & 100 \\
filler & silica & $\mathrm{ZnO}$ & aerosil & C. B. & $\mathrm{CaCO}_{3}$ & talc \\
filler $/ \mathrm{phr}$ & 10.0 & 27.3 & 10.1 & 8.6 & 13.0 & 13.0 \\
density of filler $/ \mathrm{g} / \mathrm{cm}^{3}$ & 2.0 & 5.7 & 2.1 & 1.8 & 2.7 & 2.7 \\
setting temperature $/{ }^{\circ} \mathrm{C}$ & 100 & 100 & 100 & 100 & 100 & 100 \\
rotational frequency $/ \mathrm{rpm}$ & 80 & 80 & 80 & 80 & 80 & 80 \\
filling ratio/\% & 80 & 80 & 80 & 80 & 80 & 80 \\
\hline $500 \mu \mathrm{m} \geqq / \%$ & 61.6 & 41.9 & 61.2 & 59.3 & 48.2 & 40.8 \\
$297 \mu \mathrm{m} \geqq / \%$ & 40.3 & 29.0 & 40.6 & 40.5 & 29.7 & 21.8 \\
\hline
\end{tabular}

Table 4 Setting temperature of the extruder

\begin{tabular}{l|r|r|r|r|r|r|r}
\hline & C7 & C6 & C5 & C4 & C3 & C2 & C1 \\
\hline Condition I & 150 & 150 & 150 & 150 & 150 & 130 & 120 \\
Condition II & 120 & 80 & 120 & 120 & 120 & 120 & 100 \\
Condition III & 120 & 80 & 100 & 120 & 120 & 120 & 100 \\
Condition IV & 100 & 60 & 80 & 100 & 100 & 100 & 80 \\
\hline
\end{tabular}

Values are displayed in ${ }^{\circ} \mathrm{C}$

場合と同様である. 試料温度に対してはシリカの添加部数 は顕著な影響を及ぼさなかった。シリカの添加部数を増加 させると収率も向上するが，10部以上では添加部数増加 の効果は少なかった．高温微粉砕は，高温下で強勒性の低 下した加硫ゴムに高せん断力を負荷して破壊し粉砕する方 法である.したがって，ブレード回転数や試料の充てん率 の増加, ブレード形状の変更等によって, より高いせん断 力を試料に負荷することで, 効果的に粉砕が進み微粒子成 分の収率は向上すると期待できる，しかし一方，高せん断 力の負荷により試料温度は急激に上昇し，それに伴い生成 したゴム粉の表面の可塑化と融着も進むと考えられる．試 料温度の上昇による融着を添加するシリカで効果的に防止 可能な範囲に止めつつ, 最大限のせん断力を負荷可能な粉 砕条件を設定することが微粒子成分の収率向上につながる と考えられる. Table 3 にシリカ以外のフィラーを添加し て高温微粉砕を行った場合の結果を示す. シリカ以外のフ イラーを用いた場合は，カーボンブラックや乾式シリカを 用いた場合にシリカと同様の良好な結果が得られた。

\subsection{2 軸押出機による高温微粉砕}

試料にシリカを 10 重量部予備混合した後， 2 軸押出機 に投入して連続プロセスで高温微粉砕を行った. Fig. 7 に 使用した 2 軸押出機のシリンダーの構造とスクリュー構成 を，Table 4 に検討したシリンダー温度設定を示す．C6

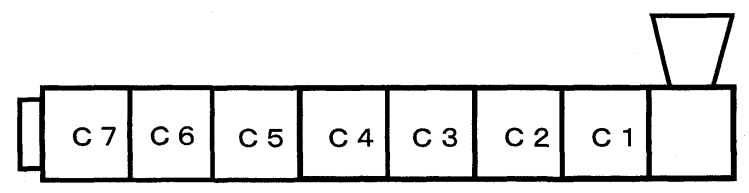

(1) KKLLL L KKKLL L KKKLKKL L L L

(2)

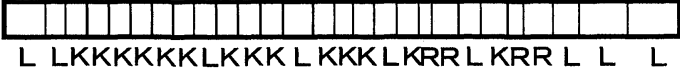

(3)

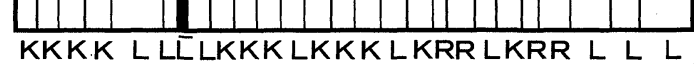

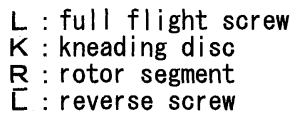

Fig. 7 Barrel structure and screw composition of the extruder.

のゾーンにはベントロが開いており, ベントロ部分ではシ リンダーの上部が開放された構造になっている.スクリュ 一構成の(1)は，プラスチックにフィラーを高充てんするた めに設計されたスクリュー構成であり，比較的高いせん断 力を負荷できる構成である. (2)は，(1)をべースとしてより 高せん断力を負荷できるようにニーディングディスクやロ ーターセグメントを多数組み込んだスクリュー構成であ る. (31は，ベントロ前のC5のゾーンにおいて試料が高充 てん状態となるように逆送スクリューを組み込むととも に，C5の部分に高せん断力を負荷できるニーディングデ イスクを連続して組み込んだスクリュー構成である.

Table 5 に 2 軸押出機を使って高温微粉砕を行った結果 を示す．NBR試料を使った結果では，スクリュー構成が 同じであれば，フィード量を増加することおよびスクリュ 一回転数を増加することで, $500 \mu \mathrm{m}$ 以下と $297 \mu \mathrm{m}$ 以下 の粒径成分の収率向上が認められた．スクリュー構成を変

Table 5 High-temperature fine grinding result by the twin screw extruder

\begin{tabular}{|c|c|c|c|c|c|c|c|c|c|c|}
\hline & $E-1$ & $E-2$ & $E-3$ & $E-4$ & $E-5$ & $E-6$ & $E-7$ & $E-8$ & $E-9$ & $E-10$ \\
\hline rubber & NBR & NBR & NBR & NBR & NBR & NBR & NBR & NBR & NBR & SBR \\
\hline rotational frequency/rpm & 200 & 200 & 100 & 200 & 100 & 200 & 200 & 200 . & 200 & 200 \\
\hline sample feed $/ \mathrm{kg} / \mathrm{h}$ & 15 & 5 & 15 & 15 & 10 & 10 & 20 & 20 & 20 & 20 \\
\hline screw composition & (1) & (2) & (2) & (2) & (3) & (3) & (3) & (3) & (3) & (3) \\
\hline setting temperature & $\mathrm{I}$ & $\mathrm{I}$ & $I$ & $\mathrm{I}$ & $\mathrm{I}$ & $\mathrm{I}$ & $\mathrm{I}$ & II & III & III \\
\hline $500 \mu \mathrm{m} \geqq 1 \%$ & 46.5 & 35.0 & 46.4 & 50.0 & 66.6 & 71.4 & 78.0 & 73.6 & 82.0 & 78.1 \\
\hline
\end{tabular}


えた場合は，より高せん断力が負荷できると考えられるス クリュー構成において良好な結果を示した．特に高充てん 状態で高せん断力の負荷が可能な(3)のスクリュー構成で粉 砕を行った場合は，(1)，(2)の場合と比較して，500 $\mu \mathrm{m}$ 以 下と $297 \mu \mathrm{m}$ 以下の粒径成分の収率が大幅に向上した。(3) のスクリュー構成ではC5のゾーンにおいて大きな試料温 度上昇が生じていると考えられる。しかし，低い設定温度 で収率が若干向上する傾向を示すものの，C5での設定温 度 $150{ }^{\circ} \mathrm{C}$ の条件においても融着を生じることなく高い収率 で微粒子成分が回収可能であった。試料投入から回収まで の時間が(3)スクリュー構成の場合でも 1 分程度と短く, 過度の可塑化が進むまで高温に曝されていないためである と考えられる。

検討した条件の範囲では， 2 軸押出機を用いた高温微粉 砕においては，微粒子成分の収率には，スクリュー構成の 設定が最も大きな影響を与えた. スクリュー回転数やフィ ード量の操作以上に, 試料に負荷するせん断力やシリンダ 一内での試料の充てん率に対して影響を及ぼすためである と考えられる.SBR試料を用いた場合においても NBR 試 料で最も良好な結果を得た条件で粉砕することで，高収率 で微粒子成分を回収可能であった。

\section{4. 結言}

混練装置を利用した高温微粉砕によって，加硫ゴムを高 効率で微粉砕可能であることを確認した．小回りのきく混 練装置を用い，小ロットで効率良く加硫ゴムを微粉砕可能 な高温微粉砕は，加硫ゴムのリサイクル技術として利用す ることが期待できる。

\section{参考文献}

1) Terasawa, H., Matusaki, T., Kuratomi, T. : Nippon Gomu Kyokaishi, 52, 271 (1979)

2 ) “Gomu Kogyo Binran 4td Ed.", Nippon Gomu Kyokai Ed., 1323(1994)
3 ) Nihon Gosei Gomu Co., Ltd. : “JSR HANDBOOK”, 189(1985)

4) Kuranashi, Y., Obana, K. : JP, 07-205146 (1995)

5 ) Kuranashi, Y., Obana, K., Matsumoto, H. : JP, 07-290456 (1995)

6 ) Taniguchi, T., Sato, N., Matsushita, M.,Takahashi, H., Suzuki, T., Hoshino, Y., Abe, N. : Kobunshi Ronbunshu, 56, 709, 717(1999)

7 ) Tatsuda, N., Sato, N., Fukumori, K., Ohta, T., Takahashi, N., Ikeda, S., Kito, M., Iwai, H. : Kobunshi Ronbunshu, 57, 412 (2000)

8 ) Tatsuda, N., Sato, N., Fukumori, K., Takahashi,N., Ikeda, S., Kito, M., Iwai, H. : Kobunshi Ronbunshu, 57, 419(2000)

9 ) Cao, Minh, Thai, Saya, S., Fukaya, T. : Plastics Age, 48, Rinjizokango, 73(2002)

10) Mouri, M., Sato, N., Okamoto, H., Matsushita, M., Honda, H., Nakashima, K., Takeuchi, K., Suzuki, Y., Owaki, M. : Nippon Goти Kyokaishi, 72, 43, 50, 278, 283(1999)

11) Fukumori, K. : Nippon Gomu Kyokaishi, 75, 79 (2002)

12) Hisamatsu, N., Nakano, T., Goto, S., Kuriyama, T. : Yamagataken Kogyogijutu Center Hokoku, 34, 9 (2002)

13) Toh, M. : JP, 07-314447 (1995)

14) Toh, M., Gondoh, T., Asahara, Y., Mori, T., Murakami, Y., Okai, D. : Full texts of International Rubber Conference, Kobe, 5 (1995)

\section{日本語表記参考文献}

1）寺沢広，松崎俊雄，倉富健郎：日ゴム協誌，52，271(1979)

2）日本ゴム協会編：ゴム工業便覧く第四版>, 日本ゴム協会, 1323(1994)

3 ）日本合成ゴム編：JSR HANDBOOK 改訂新版第 2 版，189(1985)

4 ）椋梨芳蔵，尾花一克：特開平 7-205146(1995)

5 ）椋梨芳蔵，尾花一克，松本浩和：特開平 7-290456(1995)

6 ) 谷口拓未, 佐藤紀夫, 松下光正, 高橋秀郎, 鈴木敏之, 星野雄 司，安部成昭：高分子論文集，56，709，717(1999)

7 ) 龍田成人, 佐藤紀夫, 福森健三, 太田 隆, 高橋直是, 池田貞 雄，鬼頭 誠，岩井久幸：高分子論文集，57，412(2000)

8 ）龍田成人, 佐藤紀夫, 福森健三, 高橋直是, 池田貞雄, 鬼頭 誠，岩井久幸：高分子論文集， 57，419(2000)

9 ）カオ・ミン・タイ, 佐谷志保子, 深谷太郎：プラスチックスエ ージ，48，臨時増刊号，73(2002)

10）毛利 誠，佐藤紀夫，岡本浩孝，松下光正，本多秀亘，中島克 己, 竹内勝政, 鈴木康之, 大脇雅夫：日ゴム協誌，72，43，50, 278, 283(1999)

11）福森健三：日ゴム協誌，75，79(2002)

12）久松德郎, 中野 哲, 後藤喜一, 栗山 卓: 山形県工業技術七 ンター報告，34，9(2002)

13）藤 道治：特開平 7-314447(1995) 